Boom juridisch

Postbus 85576

2508 CG Den Haag

T (070) 3307033

E info@bju.nl

www.boomjuridisch.nl

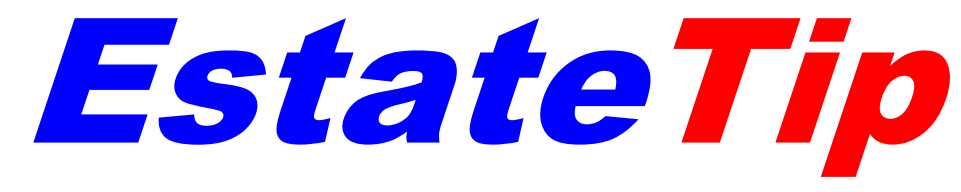

\title{
Hoe passen de Nederlandse erfrechtelijke sterren in de internationale hokjes?
} Een Europese verklaring van executele

Binnen de Nederlandse grenzen zwaait de executeur altijd de erfrechtelijke scepter, geen probleem, al is het maar omdat hij handelt met uitsluiting van anderen. Maar hoe is het als hij erfrechtelijk over de grenzen heen opereert, ofwel zijn sterren in het buitenland wil laten stralen? Daar heeft hij in ieder geval een erfrechtelijk visum nodig: een Europese verklaring van erfrecht. Dit erfrechtelijk paspoort zal door de notaris verstrekt worden. Bij dit document hoort, zoals bekend, een formulier, waarin 'hokjes' aangevinkt moeten worden over de bevoegdheden, ofwel: de sterren van de executeur. Ons Nederlandse erfrechtelijk gesloten stelsel helpt daar bij, aangezien dit systeem ook een soort van 'hokjesdenken' inhoudt. Ons gesloten stelsel zorgt ervoor dat de notaris niet uit de bocht vliegt en wat de executeur betreft niet alleen in hokjes, maar vooral ook in sterretjes denkt.

Een Nederlandse notaris moest, nadat hij een Europese verklaring van erfrecht had afgegeven, op het matje komen bij de notariële tuchtrechter. Wat was er aan de hand? Het ging over de bevoegdheden van de Nederlands executeur over de grens, in dit geval ten aanzien van een onroerende zaak gelegen bij onze oosterburen. Niet zomaar maar een land, maar het land van de oer-executeur: 'der Testamentsvollstrecker'. Er had met betrekking tot de bevoegdheden van de executeur op het formulier niet de juiste nuancering plaatsgevonden, waardoor de Duitse notaris een verkeerde conclusie trok. Ik heb vanmiddag nog maar eens, met enige erfrechtelijke melancholie, door mijn proefschrift gebladerd. Al bladerend lees ik op p. 553 over de ware aard van de executeur een verwijzing naar de dissertatie van Carolin Lauer, (Würzburg 1999, p. 3) die aangaf dat de Duitse Testamentsvollstrecker een van de sterkste executeurs ter wereld is, maar ik voegde daar aan toe:

'Naar mijn mening heeft het onderhavige onderzoek aangetoond dat de Nederlandse executeur-afwikkelingsbewindvoerder de Testamentsvollstrecker voorbijgestreefd is en daarmee in ieder geval in Europa voorop loopt.'

Hoop voor de betreffende notaris? Let wel: in het onderhavige geval ging het niet om een afwikkelingsbewindvoerder, maar om een beheersexecuteur, 'slechts' twee sterretjes. In de verklaring van erfrecht staat:

'De executeur is bevoegd de door hem beheerde goederen te gelde te maken, voorzover dit nodig is om de schulden van de nalatenschap te betalen. Gedurende het beheer vertegenwoordigt de executeur de erfgenamen waar het de nalatenschap 
betreft. De executeur is ook bevoegd namens de erfgenamen met zichzelf, als schuldeiser van de nalatenschap, te handelen.'

En die is nu eenmaal wat lichter dan zijn grotere broer, die zelfs - als het aan erflater ligt zelfstandig, zonder medewerking van wie dan ook, kan verdelen of anderszins beschikken. In de woorden van de Kamer voor het Notariaat in het ressort ArnhemLeeuwarden, uitgesproken op 30 oktober 2019, ECLI:NL:TNOARL:2019:61:

'5.2. Ter gelegenheid van de mondelinge behandeling heeft de toegevoegd notaris, bij monde van haar gemachtigde, toegegeven dat zij heeft nagelaten onder "sonstiges" onder 4.23 op het formulier van de Europese verklaring van erfrecht de bevoegdheid van de executeur te nuanceren. De toegevoegd notaris meent echter dat dit niet zo klachtwaardig is dat het een maatregel van de kamer rechtvaardigt: zij hoefde immers de bevoegdheid van de executeur niet te nuanceren, omdat de Duitse notaris op de hoogte was van het testament (en dus van de beperkte bevoegdheid van de executeur). Daarbij zou het volgens haar ook niet noodzakelijk zijn, op grond van aspecten van internationaal privaatrecht.'

Er was blijkbaar geen sprake van een afwikkelingsbewind ofwel van een derde ster in de zin van artikel 4:171 BW. Welk hokje heeft de notaris dan aangekruist?

'5.3. De kamer is van oordeel dat de klacht gegrond is. Vast staat dat de toegevoegd notaris door het aankruisen van de bevoegdheid "Vermögensbelastungen übertragen oder begründen" (het leveren, overdragen of bezwaren van goederen) op het formulier van de Europese verklaring van erfrecht de executeur een ruimere bevoegdheid heeft gegeven dan hem op grond van de verklaring van executele toekwam. Zij mocht er niet op vertrouwen dat de Duitse notaris uit het testament moest begrijpen dat die bevoegdheid beperkter diende te worden opgevat. Dat geldt temeer nu in Duitsland van een ruimere bevoegdheid van een executeur wordt uitgegaan. Zij had daarom op dat formulier onder "sonstiges" de bevoegdheid van de executeur zoals vermeld in de verklaring van erfrecht van 16 januari 2018 dienen te noteren.'

Maar een foutje maken is toch menselijk, ook voor een notaris:

'5.4. Niet is komen vast te staan dat de toegevoegd notaris bewust een toevoeging over de (beperktere) bevoegdheid van de executeur op het formulier heeft weggelaten om hem in de gelegenheid te stellen de woning aan een derde te verkopen.'

Dat klinkt nog allemaal redelijk en begrijpelijk, maar er volgt toch, naast een kostenveroordeling voor behandeling van de klacht door de kamer, notariële 'straf': 'De kamer acht de maatregel van waarschuwing passend en geboden.' Pas op met het internationaal spelen met sterretjes, waarbij ik wel aanteken dat men met het bepaalde, ofwel de externe vertegenwoordigingsbevoegdheid in artikel 4:145 lid 2 BW een heel eind komt in het rechtsverkeer, ook als de interne spelregels wat minder zijn. Bij dit laatste doel ik uiteraard op de interne beperking van de koppeling van de bevoegdheid aan de schulden van de nalatenschap als bedoeld in artikel 4:147 BW. Zij het dat de Hoge Raad in de in Nederland wereldberoemde rechtsoverweging 4.2 in zijn arrest van 21 november 2008, NJ 2009/116 zonder enig erfrechtelijk blad voor de mond, voor eeuwig liet optekenen: 
'De executeur aan wie, zoals hier het geval is, het bezit van de goederen van de nalatenschap is toegekend en die is aangesteld tot beredderaar van de boedel, is bevoegd met uitsluiting van anderen het beheer over de goederen van de nalatenschap te voeren. Op grond van deze bevoegdheid mag hij het beheer naar eigen inzicht voeren en de keuzes maken die hem ten behoeve van dat beheer geraden voorkomen, zij het dat hij daarbij de zorg van een goed executeur moet betrachten. Hij is bevoegd om goederen van de nalatenschap te verkopen ten behoeve van de afwikkeling van de nalatenschap, bijvoorbeeld teneinde een schuld uit een legaat of een (andere) schuld van de nalatenschap te voldoen.' (Curs. BS)

Maar we hadden kunnen weten dat notariële tuchtrechters niet altijd denken in termen van externe en interne bevoegdheden. Wellicht is de betreffende hierboven aangestipte Nederlandse verklaring van executele met het oog op externe werking al niet ideaal, en had die misschien al wat meer op artikel 4:145 lid 2 BW geschreven dienen te worden (de externe vertegenwoordigingsbevoegdheid in het rechtsverkeer) en wat minder moeten verwijzen naar de interne beperking, maar dat 'tuchtrechtelijk' terzijde.

Het leerzame van de uitspraak is in ieder geval dat wij nog alerter zullen zijn op de werking van ons mooie gesloten stelsel in combinatie met de sterretjes van de executeur.

Notaris, kijk goed welk hokje u aankruist. Het staat in de sterren. Laat ze niet te onbeperkt stralen over het Europees erfrechtelijke land.

Tot volgende week!

Prof. mr. dr. B.M.E.M. Schols

ScholsBurgerhartSchols Estate Planning

Radboud Universiteit Nijmegen

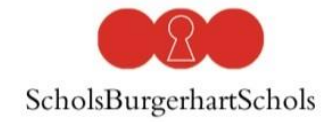

\section{Boomjuridisch}

www.scholsburgerhartschols.nl www.boomjuridisch.nl

(C) 2019 Boom juridisch | ScholsBurgerhartSchols

Hoewel de uiterste zorg is besteed aan de inhoud van EstateTip Review aanvaarden de uitgever en de redactie geen aansprakelijkheid voor onvolledigheid of onjuistheid. 